Harris, G. W. (1950). F. Physiol. (Lond.), 111, 347. (1955). Neural Control of the Pinuizary Gland. Arnold, London and Jacobsohn. D. (1952). Proc. roy. Soc. B, 139, 263.

Houssay, B. A., Biasord, A., and Sammartino, R. (1935). C.R. Soc. Biol. (Paris), 120, 725.

Le Beau, J., and Poncin, J. F. (1960). Acta psychiat. scand., 35, 13. Luft, R., and Olivecrona, $\dot{H}$. (1953). 7. Neurosurg., 10, 301.

(1957). Cancer (Philad.), 10, 789.

McConnell, E. M. (1953). Anat. Rec., 115, 175. W. J. (1957). f. clin. Endocr., 17, , 1277 .

Murdoch, R. (1962). Lancet, 1, 1327.

Pinkerton, P. H., and Adams, J. H. (1961). Scot. med. Y., 6, 156.

Popa, G. T., and Fielding, U. (1930). F. Anat. (Lond.), 65, 88.

Purves, H. Ḋ., and Griesbach, W. E. (1951). Endocrinology, 49, 244.
Rinne, U. K. (1960). Acta endocr. (Kbh.), 35, Suppl. No. 57.

Russeh, D. S. (1956). Lancet, 1, 466.

Sheehan, H. L. (1937). F. Puih. Bact., 45, 189.

- and Summers, V. K. (1949). Quart. f. Med., 18, 319.

Smith, P. E. (1927). F. Amer. med. Ass., 88, 158.

- (1930). Amer. F. Anat., 45, 205.

(1932). Anat. Rec 52,191

Stanfield, J. P. (1960). \%. Anat. (Lond.), 94, 257.

Van Buren, J. M., and Bergenstal, D. M. (1960). Cancer (Philad.), 13 155.

Worthington, W. C., iun. (1955). Bull. Fohns Hopk. Hosp., 97, 343.

Xuereb, G. P., Prichard, M. M. L., and Daniel, P. M. (1954a). Quart. f. exp. Physiol., 39, 199

\title{
"Epidemic Collapse" : A Mysterious Outbreak in Three Coventry Schools
}

\author{
G. T. POLLOCK,* M.B., CH.B., D.P.H. ; T. MORRISON CLAYTON, $†$ M.D., B.HY., D.P.H.
}

\author{
Brit. med. F., 1964, 2, 1625-1627
}

During the past three decades there have been several reports of explosive outbreaks of a syndrome characterized by nausea (sometimes accompanied by vomiting), vertigo, headache, and a varying degree of collapse. The condition usually occurs in children of school age, and girls seem to be affected more often than boys. Miller and Raven (1936) were among the earliest workers in this country to draw attention to the condition in their description of a typical outbreak at a girls' boardingschool ; this episode was considered by these authors to resemble very closely two outbreaks which had been reported from Denmark during the previous year. Similar occurrences, also in girls' schools, were described by Gray (1939), Bradley (1943), and MacDougall (1954); and Haworth et al. (1956) reported a typical outbreak affecting patients and staff in a children's hospital.

The following is a brief account of a comparable outbreak affecting 404 pupils and two members of staff at three Coventry schools in the early part of 1964 , and it is interesting to note that it bears a remarkable resemblance to an unpublished study relating to a similar occurrence in Montgomeryshire in 1961. The term "epidemic collapse" is used in this account to describe the condition, as actual collapse was the most striking feature.

\section{The Outbreak}

In the early afternoon of Friday, 31 January 1964, we received information by telephone that during the previous few hours a dozen or so girls at a secondary modern school in the city (School A) had become ill with nausea, giddiness, and collapse. The school, a well-designed post-war building, was immediately visited and a scene of great confusion was found. The affected girls, aged 12 to 14 years and from three different classes, were lying on blankets and coats in the gymnasium, looking acutely ill, and other girls in a collapsed state were being carried to the gymnasium from the classrooms.

The clinical picture was fairly uniform; without any obvious warning there would be the sudden onset of frontal headache, nausea, and violent shivering, with colicky upper abdominal pain, giddiness, and a feeling of faintness. In nearly all cases the girls were in a collapsed state and unable to stand

- Deputy Medical Officer of Health, City of Coventry.

+ Medical Officer of Health, City of Coventry. or, in some cases, even sit. There was little actual vomiting and no diarrhoea. Physical examination proved almost completely negative apart from a suspicion of cyanosis about the lips and in the extremities in a few cases ; all the girls looked and felt very cold but not, it was interesting to note, with the clammy type of skin which one usually associates with a faint. There was no pyrexia, the pulse rate tended to be only slightly raised, and there was no significant lowering of the bloodpressure as one would expect in a simple faint. It appeared that most girls felt much better after lying down for about an hour or so.

In the light of the above the first question that had to be urgently considered was the possibility of a toxic gas and/or poor ventilation being responsible for the symptoms, but immediate investigation did not bear out this theory. The school is heated by an oil-fired heating plant sited well away from the main school building and only hot-water pipes enter the classrooms therefrom. The weather at the time was cold but brilliantly sunny, and consequently, in view of the very large window area, adequate cross-ventilation had been ensured by opening windows on each side of the classrooms. Coal-gas is not used in the school and there has never been any trouble with the drains.

The next consideration was that the symptoms might possibly be caused by food or drink, but on questioning the affected girls it appeared that the condition was not related to the taking of school meals or school milk, and, in fact, most of the girls had become ill during mid-forenoon. However, to be on the safe side, samples of food, milk, water, and tuck-shop confectionery-for example, marshmallow biscuits and potato crisps-were sent for bacteriological and chemical examination. This proved quite easy, as it is the practice in Coventry to retain samples of all foodstuffs from each sitting of school meals for a period of 48 hours so that analysis can be readily carried out in the event of food-poisoning being suspected.

Having provisionally excluded the above two causes a tentative diagnosis of undetermined virus infection was made, as it was thought that the clinical picture had many features in common with the conditions described variously as "epidemic vertigo," "epidemic nausea," and "winter vomiting disease." Accordingly, in consultation with the director of the Coventry Public Health Laboratory, throat swabs were taken from some of the most acutely ill cases and the material was sent for virus culture. 
Further cases occurred during the afternoon, the total reaching 35 by the end of the day. With the exception of one case mentioned below, all the girls were able to be sent home by ambulance, and advice was given that their parents should call the family doctor if the condition had not improved within an hour or so. One girl appeared to be considerably more ill than the others, developed hysterical overbreathing and carpopedal spasm, and was admitted to the local isolation hospital.

As the day of onset was a Friday it was thought possible, on the assumption that the condition was a virus infection, that the advent of the week-end might prevent further spread of the outbreak. However, on Monday, 3 February, a further 35 girls developed similar symptoms, and in addition a substantial proportion of the girls who had been ill on the previous Friday but who had returned to school feeling well on the Monday morning seemed to suffer a relapse, and a total of some 60 girls had to be sent home. On the same day one case was reported at the near-by boys' secondary modern school (School B), which is on the same site as School A, and seven cases occurred at another girls' secondary modern school (School C) in a different part of the city, although these last cases were not reported at that time as they did not seem to have any particular significance. From this point cases continued to occur in successive waves at all three schools, as is shown in the Chart, and it is interesting to note that a few sporadic cases had occurred prior to the explosive outbreak starting on 31 January.

By this time negative results had been received in respect of all bacteriological and chemical tests on food, milk, water, etc., and this tended to add support to the theory that the condition was a virus infection spread by close contact with cases or with those incubating the condition, in spite of the fact that no virus was subsequently cultured in the laboratory. The mode of spread of infection was regarded as probably by droplet spray, and consequently from the fourth day of the outbreak, when it was obvious that the week-end break was insufficient to prevent the spread of infection, it was decided to exclude each case for an arbitrary period of seven days (as this has often been found to be effective in winter vomiting disease), even though recovery from symptoms appeared to occur, as a rule, after 72 hours. In spite of this measure, however, cases continued to occur at an alarming rate. The outbreak was given considerable press publicity, and an invitation to make use of the regional radio and television facilities was accepted in order to provide further public reassurance.

At the beginning of the following week it was disconcerting to find that there were many relapses in children who had

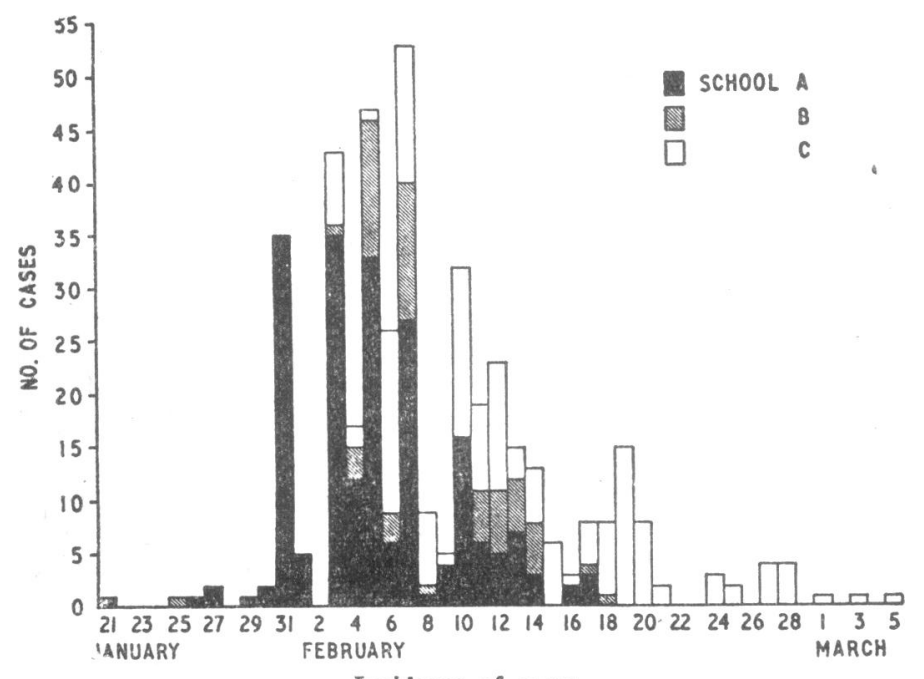

returned to school after a week's absence, and it was decided to extend the exclusion period to 14 days to allow more complete recovery ; but as further cases continued to occur it became necessary to advise the Director of Education to close Schools $\mathrm{A}$ and $\mathrm{B}$ for a two-weeks period from 17 to 28 February inclusive. School C was not so greatly involved, and after discussion with the head teacher it was considered inappropriate to close this school. Those affected, however, were excluded for a period of 14 days. No further cases occurred among the girls or boys of Schools A or B, but for the next two or three weeks a few cases were reported from School C.

When the epidemic was finally over a detaliled retrospective study was carried out by the submission of a questionary for completion in respect of each person affected. The Table, which contains information based on the study, gives a detailed picture of the clinical and other relevant features noted during the outbreak.

\begin{tabular}{|c|c|c|c|c|c|}
\hline & & & \multicolumn{3}{|c|}{ Proportion of } \\
\hline & & & All Pupils & Girls & Boys \\
\hline 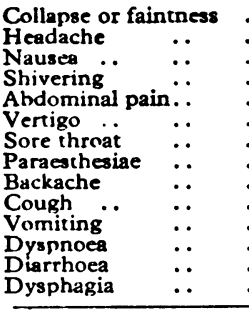 & $\begin{array}{l}\because \\
\because \\
\because \\
\because \\
\because \\
\because \\
\because \\
\because \\
\because \\
\end{array}$ & $\begin{array}{l}\because \\
\because \\
\because \\
\because \\
\because \\
\because \\
\because \\
\because \\
\therefore \\
\end{array}$ & $\begin{array}{l}96 \% \\
76 \% \\
68 \% \\
62 \% \\
53 \% \\
49 \% \\
28 \% \\
18 \% \\
18 \% \\
17 \% \\
16 \% \\
15 \% \\
11 \% \\
9 \%\end{array}$ & $\begin{array}{l}98 \% \\
77 \% \\
67 \% \\
64 \% \\
51 \% \\
50 \% \\
29 \% \\
19 \% \\
20 \% \\
15 \% \\
16 \% \\
17 \% \\
11 \% \\
10 \% \\
\end{array}$ & $\begin{array}{l}90 \% \\
71 \% \\
74 \% \\
47 \% \\
69 \% \\
45 \% \\
17 \% \\
12 \% \\
71 \% \\
21 \% \\
17 \% \\
22 \% \\
12 \% \\
9 \%\end{array}$ \\
\hline $\begin{array}{l}\text { Relapsed } \\
\text { Family doctor called } \\
\text { Associated family case( }\end{array}$ & $\ddot{\ddot{s})}$ & $\begin{array}{l}\ldots \\
\cdots\end{array}$ & $\begin{array}{l}24 \% \\
23 \% \\
26 \%\end{array}$ & $\begin{array}{l}26 \% \\
24 \% \\
25 \%\end{array}$ & $\begin{array}{l}14 \% \\
16 \% \\
33 \%\end{array}$ \\
\hline Mean duration of symp & ptoms & .. & $3 \cdot 1$ days & $3 \cdot 2$ days & 2.6 days \\
\hline
\end{tabular}

\section{Discussion}

It will be observed from the Table that the clinical picture was essentially one of symptoms rather than signs, and in view of this we had to consider the possibility of the condition being psychogenic ; indeed, the principal symptoms complained of are relatively common psychogenic manifestations, especially in persons of this age-group.

However, there were many features which tended to point to an infectious origin, viral rather than bacterial, in spite of the lack of laboratory confirmation. Firstly, the explosive onset affecting a large number of persons after a few days of "smouldering" cases, followed by well-defined successive waves as shown in the Chart, is suggestive of a communicable condition with an incubation period of perhaps two to three days. Secondly, the boys affected initially at School B were, in the main, the brothers of the affected girls at School A. (It is interesting to note that no cases occurred at the girls' grammar school, which is geographically situated midway between Schools A and B and within 100 yards of each. The girls attending this grammar school have little contact with the pupils of Schools A and B, and their brothers, in most cases, attend a boys' grammar school on the opposite side of the city.) Thirdly, there were reports of a significant number of instances in which adult and pre-school-child home contacts developed roughly similar symptoms. Fourthly, the outbreak had many features in common with other outbreaks which have been reported from time to time in different parts of the country. Fifthly, the closure of Schools A and B brought the outbreak to an immediate end in those schools.

Although there is no doubt that in a small number of instances the symptoms were hysterical there was little difficulty in distinguishing these, and, in fact, these pupils were well known to the school staff for their minor psychoneurotic reactions-for example, fainting, sickness, etc. Indeed, the 
impression of the teachers was that the majority of affected pupils were sensible and emotionally stable.

As to the system affected by the infection, the sudden onset of severe frontal headache associated with vertigo and faintness tended to point to an involvement of the central nervous system rather than of the gastro-intestinal tract, and it was certainly feasible to consider the nausea to be of "central" origin. Conversely, the relatively small amount of vomiting and diarrhoea and the absence of pyrexia tended to exclude the gastro-intestinal system, especially in the absence of any association with a particular food or drink.

The duration of symptoms was rather longer than is usual in this type of condition; the slightly shorter period for boys was probably not really significant, and it may simply reflect differences between boys and girls in psychological response to illness. It was not possible to define a period of communicability, but it appeared to be greater than one week-again rather longer than is usual in outbreaks of this character. The relapse rate was very disturbing, and it was not possible to offer an explanation for this phenomenon, but certain features suggested an hysterical element.

This outbreak serves to illustrate the practical difficulties experienced by a public health medical officer in dealing in a rapid and effective fashion with "group illness" in a localized community of this nature. The initial difficulty was that of making an on-the-spot diagnosis adequate for the purposes of disposal of cases and the taking of immediate action to prevent the occurrence of further cases (it may well be imagined that a school gymnasium giving the impression of a "casualtyclearing station " is hardly an ideal situation in which to practise careful diagnostic technique). In this instance it did not prove too difficult to exclude gaseous poisoning, but this might not have been so straightforward had the school been of an older type using coal-gas and possibly with defective drains. The second problem was that of the logistics of case disposal; it was found that a substantial number of ambulance vehicles (sitting-case cars) had to be used daily, and this involved considerable rearrangement of other non-emergency ambulance duties. The third and possibly most difficult problem was that of the public-relations aspect of the matter ; the condition was soon being discussed by the public at large as the "Coventry mystery virus," but, with the help of the school staff initially and subsequently the co-operation of the press and regional television news broadcasting service, it was possible to utilize the publicity to good purpose.

\section{Summary}

An explosive outbreak affecting 404 pupils and two members of staff at three Coventry secondary modern schools is described, in which the prominent symptoms were frontal headache, nausea, and vertigo, accompanied by actual collapse.

Arguments are put forward for considering the outbreak to be of infectious (probably viral) origin, although it is admitted that hysterical elements were probably also present.

An account is given of the attempted measures of control, drawing attention in particular to the part played by exclusion and finally by school closure.

Mention is made of the practical difficulties involved in dealing with an outbreak of this type of "group illness" in a localized community.

We should like to express our gratitude to Dr. J. E. M. Whitehead, Director of Coventry Public Health Laboratory, for his valuable advice during the outbreak. We are also greatly indebted to $\mathbf{M r}$. W. L. Chinn, Director of Education, City of Coventry, for his co-operation; and to Sister Colman, Miss D. M. Parncutt, and Mr.

T. M. Hope, the head teachers of the three affected schools, for the calm yet smoothly efficient manner in which they coped with the highly dramatic and totally unprecedented situation in their schools.

\section{REFERENCES}

Bradley, W. H. (1943). Brit. med. f., 1, 309.

Gray, J. D. (1939). Ibid., 1, 209

Haworth, J. C., Tyrrell, D. A. J., and Whitehead, J. E. M. (1956). Lancei, 2, 1152.

MacDougall, I. A. (1954). Annual Report of the Principal School Medical Otficer for Hampshire, p. 9.

Miller, R., and Raven, M. (1936). Brit. med. F., 1, 1242.

\title{
Laboratory Infection with Louping-ill Virus : a Case Study*
}

\author{
WILLIAM C. COOPER, $†$ M.C. ; IRVING J. GREEN, M.SC. ; JAMES W. FRESH,§ M.c.
}

Louping-ill is primarily a disease of sheep in the British Isles, but a few cases have been reported in man; all of them have been in laboratory workers or persons handling sheep, such as abattoir workers, in enzootic areas (Rivers and Schwentker, 1934 ; Davison et al., 1948 ; Edward, 1948 ; Lawson et al., 1949). The aetiological agent of louping-ill is a group B arbovirus closely related to the Russian tick-borne complex which also includes Far Eastern Russian spring-summer encephalitis,

* From the Clinical Investigation Department, United States Naval Medical Research Unit No. 2 (NAMRU-2), Taipei, Taiwan, Republic of China This study was supported in part by funding under Public Law 480 , Section 104(c). The opinions and herein 48 , Section 104 (c). The opinions and asserdons contained flecting the views of the Navy Department flecting

† Lieutenant Commander, U.S.N. ; Clinical Investigator, United States Naval Medical Research Unit No. 2.

‡Lieutenant Commander, U.S.N. ; Present address: University of Callfornia Medical Center, Los Angeles, California.

5 Lleutenant Commander, U.S.N.; Pathologist, United States Naval Medical Research Unit No. 2.
Omsk haemorrhagic fever, Central European tick-borne virus encephalitis, and Kyasanur Forest disease of India. The vector for these diseases is thought to be the infected tick, although Soviet scientists have shown the Central European encephalitis may be acquired by drinking milk from infected goats (Smorodintsev et al., 1954). In the case of louping-ill, natural infection in man presumably occurs after a tick-bite in persons handling tick-infected sheep. The routes of laboratory infection in most human cases have been unknown.

In several reported cases louping-ill in man has been described primarily as non-fatal meningoencephalitis with certain characteristics common to the whole group of Russian tickborne encephalitides (Rivers and Schwentker, 1934 ; Davison et al., 1948 ; Edward, 1948 ; Lawson et al., 1949 ; Rivers and Horsfall, 1959). These features are: (1) abrupt onset and a diphasic course of symptoms ; (2) an influenza-like initial phase marked by fever, systemic symptoms, and leucopenia ; (3) a second phase characterized by central nervous system symptoms 